\title{
Partial democratization and healthcare reforms in a post-communist hybrid regime: The case of Georgia
}

\author{
ANDREA CASSANI \\ Università degli Studi di Milano \\ Email: andrea.cassani@unimi.it
}

GABRIELE NATALIZIA

La Sapienza Università degli Studi di Roma (Italy)

Email: gabriele.natalizia@uniroma1.it

Democratization is often said to direct rulers' attention to social services. Yet how strong is this relationship in countries that had to restructure previously universalistic but financially unsustainable welfare systems, such as the post-communist states following the collapse of the Soviet bloc? And what if political change stops short of full democratization leading to hybrid regimes in which elements of competitive politics and authoritarianism coexist? To address these questions, we analyse health care reforms in post-communist Georgia. We posit that, even when authoritarianism is not fully eradicated, elections and a partial liberalization of the political arena could elicit rulers' responsiveness to social needs. The research highlights that the progress in political competition that followed the 2003 Rose Revolution has not made Georgia fully democratic, but has nonetheless shaped the health policy approach of the two successive governments, favouring a reconciliation between financial sustainability and citizen accessibility.

Democratization; hybrid regimes; competitive authoritarianism; healthcare; Georgia 


\section{Introduction}

Democratization - that is, the adoption and subsequent consolidation of democratic institutions such as multiparty universal suffrage elections for the main governmental offices, free and fair competition, freedom of expression and association and access to alternative sources of information (Dahl, 1971) - is said to direct rulers' attention towards social issues (Halperin et al., 2005). Scholars have found evidence of this effect both working with global samples of countries (Lake and Baum, 2001; Ghobarah et al., 2004, among others, cf. Ross, 2006) and focusing on specific world regions such as Latin America (Huber and Stevens, 2012), subSaharan Africa (Carbone, 2011), and Asia (Wong, 2004).

Yet how strong is this relationship under unfavourable conditions, such as those faced by many post-communist countries after the crisis of the Soviet bloc? Economic recession, the collapse of an existing fully state-funded welfare system and the need to restructure social service delivery on financially sustainable models represent challenges for any government. While scholars found democratization to have an alleviating effect even in similar circumstances (Cook, 2007; Haggard and Kaufman, 2008; Orenstein, 2008), scant attention has thus far been devoted to the welfare implications of the institutionalization of so-called hybrid regimes, in which democratization remains partial and some degree of political competition coexists with persistently authoritarian governance (Levitsky and Way, 2010). Is partial democratization sufficient to draw governments' attention to social needs, or is full democratization necessary?

In this article, we try to address this question focusing on the case of Georgia and the reform of its health sector. ${ }^{1}$ Several reasons justify our case selection. Just as in other post-communist countries, the economic recession that followed the crisis of the Soviet bloc (World Bank, 2002)

\footnotetext{
${ }^{1}$ To be sure, healthcare is only one component of the welfare state, but arguably an important one. Access to health services has direct and concrete consequences on citizens' lives.
} 
forced Georgia to restructure the notoriously generous but financially unsustainable socialist welfare state (Cook, 2007; Orenstein, 2008). However, political change in Georgia proceeded slowly and remained incomplete. After a coup d'état and a period of de facto one-party hegemony under Eduard Shevardnadze (Nodia and Scholtback, 2006), the 2003 Rose Revolution only led to competitive authoritarianism rather than to democracy (Hale, 2006), first under the presidency of Mikheil Saakashvili (2004-2012) and more recently under the Georgian Dream party. Most importantly, health policy in Georgia has experienced two major changes since the Rose Revolution, which we try to explain in light of the progressively higher competitiveness of the country's political arena.

The article is organized as follows. First, we review the literature on the consequences of democratization on welfare reforms in post-communist countries. The second section focuses on partial democratization and examines the incentives that rulers in competitive authoritarian regimes face to improve citizens' living conditions. The discussion highlights that even if authoritarianism is not eradicated, electoral competition in hybrid regimes could elicit rulers' responsiveness to social needs. In the third section, we study Georgia in depth to examine the connection between the partial democratic progress that Georgia has experienced following the Rose Revolution and the approach adopted by the two successive governments to restructuring the health sector.

The conclusion is that even partial democratization can direct rulers' attention to social issues. Specifically, we find that, while the Rose Revolution fell short of making Georgia fully democratic, it has favoured an approach to the reform of the health sector aimed to reconcile financial sustainability and citizen accessibility. First, through the adoption of compensatory measures for the less well-off by a government that suffered in 2008 a significant loss of ballots. Subsequently, through the introduction of free healthcare, following a second episode of government turnover in 2012 and an electoral campaign highly focused on social issues. 


\section{The welfare consequences of democratization in post-communist countries}

At the beginning of the 1990s, post-communist countries faced two interrelated yet conflicting priorities. On one hand, they had to take care of an impoverished population, as a consequence of the economic recession that hit the region after the collapse of the Soviet bloc (World Bank, 2002). On the other hand, the recession represented the knockout blow for the socialist welfare state (Cook, 2007) - renowned for its reach and generosity (Orenstein, 2008), but highly inefficient from a financial viewpoint given disproportioned costs of maintenance - and postcommunist countries had to restructure their national healthcare systems. Financial sustainability often requires cuts to public spending and service privatization, which could hinder middle-lower income citizens' access to even basic social services, especially in periods of economic slowdown (Rudra and Haggard, 2005).

Research on how post-communist governments have dealt with these challenges has highlighted that economic factors have not represented the sole drivers of welfare reforms in these countries. For instance, post-communist governments' welfare restructuring has been shaped by variables such as the involvement in the European Union's accession politics, which encouraged candidate countries not to operate extreme cuts in welfare spending to avoid social dumping (Deacon, 2000), and the type of pre-communist welfare-state traditions, if any (Inglot, 2008). A third crucial factor that has been emphasized refers to the outcomes of the democratic transitions on which several post-communist countries embarked (McFaul, 2002; Bunce, 2003; Orenstein 2008).

How could democratization influence governments' welfare decisions? The so-called 'democracy advantage' - that is, the idea that democracies 'respond more readily to people's needs' (Halperin et al. 2005, p. 22) - rests on two fundamental features of democratic politics, namely, competition and participation (Dahl, 1971), and is centred on elections. Electoral 
competition induces governments to adjust the policy agenda to the preferences of middlelower income groups, to which the decisive median-income voter arguably belongs (Meltzer and Richard, 1981). As a channel of political participation, moreover, periodic universal suffrage elections reduce the cost borne by a single individual to sanction rulers' poor welfare performance and to voice demands for social services (Lake and Baum, 2001).

While both large-N comparative analyses (Lake and Baum, 2001; Ghobarah et al., 2004) and region-specific studies (Huber and Stevens, 2008; Carbone, 2011) find evidence of a democracy-welfare relationship, the above arguments - and the underlying assumption that autocracy equals cleptocracy - have not been spared by criticisms. Ross (2006) contends that many studies omit well-performing non-democratic countries due to missing data. Olson's stationary bandit theory suggests that dynastic succession could be "socially desirable" (1993, p. 572). Luciani (1987) identifies high government spending as a defining feature of the socalled "rentier state", whereas free health was a pillar of socialist states, as already pointed out (Orenstein, 2008). Mares and Carnes (2009) notice that many early examples of welfare programs were implemented by non-democratic rulers, moreover. Finally, other scholars find that autocracies are no less likely than democracies to adopt welfare programs, even if welfare delivery is more selective in the former (Knutsen and Rasmussen, 2018; Grunewald, 2021).

Despite the existing disagreement, when attention has focused on post-communist countries, scholars tend to agree that democratization has alleviated the impact on social services of economic recession and of the welfare reforms that post-communist governments had to implement. More specifically, democratization has favoured the organization of civil society advocacy groups, giving them influence over social policy and creating strong pressures on elected governments of any colour either not to dismantle existing social protections altogether or to adopt compensatory measures (Cook, 2007; Haggard and Kaufman, 2008; Orenstein, 2008; Bohle and Greskovits, 2012). Where authoritarianism has been restored, on the contrary, 
unaccountable and repressive executives either rebutted reforms (Bunce and Wolchick, 2008) or implemented them with little consideration for their social costs (Cook, 2007).

\section{The welfare consequences of partial democratization}

In a period of economic transition that saw the collapse of the socialist welfare state, postcommunist countries embarked on momentous political transformations that shaped the way governments have dealt with the twofold challenge of taking care of an impoverished population and of restructuring social services on financially sustainable models. Scholars found that democratization has pushed post-communist newly elected governments to pay progressively increased attention to the social costs of welfare restructuring, to limit the actual level of welfare retrenchment, and/or to adopt compensatory measures for the less well-off (Cook, 2007; Haggard and Kaufman, 2008).

However, this literature has predominantly focused on cases in which democratization either has been successful (e.g. Poland, Hungary) or has failed (e.g. Russia, Belarus, Kazakhstan). Yet, in other post-communist countries (as the likes of Georgia, Armenia, Kyrgyzstan, Moldova, and Ukraine) political change has proceeded in fits and starts and has remained incomplete: while full-fledged democracy has not been achieved, outright re-autocratization has not occurred either. Instead, "hybrid regimes" (Diamond, 2002) have emerged. In these systems, elements of competitive politics - such as elections and some political pluralism coexist with persistently authoritarian governance (Levitsky and Way, 2010).

While the origins and functioning of post-communist competitive authoritarian regimes have been studied extensively (Bunce and Wolchick, 2008; Way, 2010), little attention has been devoted thus far to questions regarding the welfare implications of partial democratization in this region, if any (but see Cassani et al., 2016). Is partial democratization sufficient to draw 
governments' attention to the social costs of welfare state restructuring (in terms of citizen accessibility, for instance), or is full democratization necessary?

The literature discussed in the previous section argues that governments in democratic countries - in which citizens are free to express their preferences, opposition parties represent credible alternatives for voters, and elections are fair - should be more responsive than autocrats to social needs. Competitive authoritarian regimes lie somewhere in between democracy and autocracy, though. Opposition parties operate above ground, but elections are not fully democratic because the ruling élite abuse state power to skew the playing field and to weaken the opposition (Levitsky and Way, 2010).

Yet these countries are not fully autocratic either, and they differ even from hegemonic-party autocracies that hold façade elections in which opposition is de facto annihilated (Schedler, 2006). Contrary to other non-democratic systems, competitive authoritarian regimes are too weak to resort to massive fraud and repression, which may trigger mass revolts (Hale 2006) and international sanctions (Donno, 2013). Moreover, under competitive authoritarianism opposition groups are less prone to be co-opted than in other autocracies as they have few but real chances to win elections, especially when they join forces (Bunce and Wolchik, 2010). ${ }^{2}$ In other words, electoral uncertainty is not eradicated in these regimes and incumbents 'are forced to sweat' (Levitsky and Way, 2010, p. 12) to hold on to power.

Given the limited use they can make of vote rigging, repression, and co-optation, rulers in competitive authoritarian regimes also have to legitimize their power in the eyes of citizens (Gerschewski, 2013) and to gain support within the population. Non-democratic rulers can claim legitimacy in two main ways, drawing on either identity or performance (von Soest and

\footnotetext{
2 In the post-communist region, government alternation under competitive authoritarianism occurred in countries such as Ukraine (2004), Georgia (2004; 2012), Kyrgyzstan (2005; 2011), Moldova (2010), and Armenia (2018).
} 
Grauvogel, 2017). However, with few exceptions, competitive authoritarian regimes are 'very much a product of the contemporary world' (Diamond, 2002, p. 24), and their rulers can hardly count on deep-rooted identity sentiments, such as tradition, ideology, and nationalism (Brusis, 2016).

Instead, rulers of competitive authoritarian regimes have to focus on performance-based legitimation and seek what Easton defines 'specific support', which could be derived from 'the satisfactions that members of a system feel they obtain from the perceived outputs and performance of the political authorities' (Easton, 1975, p. 437) relative to their needs. Social services represent an effective way to elicit this kind of support. First, for rulers that need to buy off the loyalty of relatively large constituencies, social services are more convenient than private goods (Bueno de Mesquita et al., 2003) as they improve the quality of life of virtually all citizens. Second, the improvements they bring in terms of living conditions could be particularly significant for the less well-off (Travaglianti, 2017), which typically represent a large share of the population in these countries. Third, social services produce immediate and visible results that voters can unquestionably attribute to the government (Stasavage, 2005; Kjær and Therkildsen, 2013).

Besides increasing the importance that rulers in competitive authoritarian regimes should attach to social services as a way to elicit specific support among citizens, elections and a certain degree of political contestation represent means to pursue this kind of performance-based legitimation. In a partially liberalized political arena, rulers can learn about citizens' preferences and overcome the so-called "dictator's dilemma" (Wintrobe, 2007). A decrease in popular support at the polls relative to the previous votes signals dissatisfaction and helps nondemocratic incumbents adjust their policy agenda, for instance (Miller, 2015). Likewise, a fiercely contested election that ends with executive turnover may create a precedent that pushes the new government to fulfil the promises made. 
To conclude, even if not fully democratic, elections and the limited degree of political contestation that characterizes competitive authoritarian regimes could induce rulers to respond to social needs as a strategy to gain popular support, weather dissent, and hold on to power. With reference to the post-communist context, we thus posit that partial democratization and transitions to competitive authoritarianism can shape rulers' approach to welfare restructuring.

Empirical evidence on the welfare consequences of partial democratization and on welfare reforms in competitive authoritarian regimes is mixed. Miller (2015) finds that negative electoral shocks in non-democratic regimes predict increases in social welfare spending. Cassani (2017) finds competitive autocracies to outperform both military and one-party regimes in delivering education and healthcare. Other scholars contend that autocratic multiparty elections have no effect on social services (Kim and Kroeger, 2018) and find democratization to have a "threshold effect" that becomes positive only when politics is genuinely competitive (Wang et al., 2019). Taken together, these studies highlight that further investigation is needed, especially considering the relatively scarce attention that the social performance of postcommunist competitive authoritarian regimes has received thus far.

\section{Health policy reforms in post-communist hybrid Georgia}

To test whether and how partial democratization draws rulers' attention to the social costs of welfare restructuring in post-communist competitive authoritarian regimes and induce them to adjust the social policy agenda to elicit "specific support", we focus on Georgia and the reform of its health sector. For clarity, we do not claim that Georgia is representative of all postcommunist countries or of hybrid regimes as a whole. However, Georgia represents a relatively understudied but enlightening case that helps understand the implications of a partial liberalization of the political arena (i.e. a defining characteristic of competitive authoritarian regimes) for welfare restructuring (i.e. a challenge many post-communist states have faced). 
We study Georgia from a diachronic perspective, delving into three consecutive periods that correspond to as many different governments. The first period refers to the two presidential terms served by Shevardnadze (1996-2003). The second period starts with the election of Saakashvili as president in 2004 and ends with the victory of the Georgian Dream party in 2012. This parliamentary election effectively marked a second episode of government turnover, after a 2010 constitutional amendment shifted executive power from the president to the prime minister. The third period starts when the Georgian Dream party's leader Bidzina Ivanishvili took office at the end of 2012 and extends until 2019. ${ }^{3}$

The analysis is introduced by Table 1, which illustrates Georgia's performance relative to some key political, economic, and health expenditure indicators. These include the Varieties of Democracy's Electoral Democracy index, Freedom House's Freedom Status indicator, the World Health Organization data about government and out-of-pocket expenditures, and World Bank data about gross domestic product per capita and economic growth. ${ }^{4}$

As we could see in Table 1, under Shevardnadze democracy and freedom scores in Georgia remained low, indicating severe deficits in political competition and a situation of de facto oneparty hegemony (Nodia and Scholtbach, 2006), even though multiparty elections were formally held in November 1995 and 2000. The 2003 Rose Revolution breathed new life into Georgia's process of democratization, which nonetheless stopped short of making the country a fullfledged democracy. Under Saakashvili, Georgia has "developed" into a competitive authoritarian regime (Dobbins, 2014). Even the second episode of government turnover that Georgia experienced in 2012, following the electoral victory of the Georgian Dream party, has

\footnotetext{
${ }^{3}$ The analysis stops before 2020 to avoid the risk that an 'extra-ordinary' event such as Covid-19 biases the findings of a research on health reforms.

${ }^{4}$ Health expenditure data are only available from 2000 to 2018.
} 
brought only modest progress in terms of democracy and freedom (Kirchick, 2012; Freedom House).

However, after the Rose Revolution we observe a progressive and substantial increase in the financial effort devoted to the health sector by the governments that have ruled the country ever since. This is evident in all the four health expenditure indicators reported in Table 1, especially during Saakashvili's second term and the subsequent Georgian Dream's government, although the significance of the recorded improvements should be evaluated in light of Georgia's extremely negative previous performance.

Table 1 thus suggests that post-Rose Revolution partial democratization has triggered higher investment in healthcare in Georgia. Starting from these intriguing but admittedly preliminary pieces of evidence, the main goal of our analysis is to assess whether and how the partial democratic progress that followed the Rose Revolution has concretely shaped the health policymaking approach of the two governments that have ruled Georgia in the following years.

Accordingly, we first examine health policy under Shevardnadze's hegemonic-party regime, which represents a basis for comparison on which to observe changes in the policy making approach of the successive governments and thus the effect (if any) of the shift to competitive authoritarianism. We then proceed to examine health policy under Saakashvili and subsequently under Georgian Dream.

[TABLE 1 ABOUT HERE]

\section{Health policy under Shevardnadze}

Georgia had a troubled debut with multiparty politics. After independence, civil war immediately broke out in the separatist regions of South Ossetia (1991-1992) and Abkhazia (1992-1993). Moreover, Zviad Gamsakhurdia, elected in April 1991 as the country's first 
president, was ousted in December of the same year by a coup that brought to power the former soviet leader Eduard Shevardnadze as chair of an interim government. Despite the return to electoral politics at the end of 1995, Georgia's political arena remained under the hegemony of Shevardnadze, which won the 1995 presidential elections and was confirmed in office in 2000, and of his Citizens' Union of Georgia (CUG), a party mainly composed of former soviet politicians (Radnitz, 2010).

During the first part of the 1990s, Georgia recorded the most negative growth rate in the region (World Bank, 1999) and the health sector collapsed (Belli et al., 2004; Chanturidze et al., 2009). Until the mid-1990s, the Soviet Semashko system - highly centralized and based on extensive coverage and universal access to free health care - remained formally in place in Georgia (Chanturidze et al., 2009). The end of funding from Moscow and the economic crisis caused a sharp reduction of the financial resources that were necessary to maintain the system. Public health expenditure fell below 1 US dollar per person (Belli et al. 2004, p. 110) and some services almost ceased, including immunization (Gamkrelidze et al., 2002).

In 1997, a compulsory social health insurance scheme was introduced, and a State Medical Insurance Company was created to provide citizens with a relatively wide-ranging package of either free or subsidized basic services (Gamkrelidze et al., 2002). Unfortunately, the introduction of the new system was 'more a rush from the previous system than a well-thoughtout-policy direction' (Collins, 2003, p. 111). While in principle the new scheme was funded through payroll tax and transfers from the government's general budget, in practice the financial constraints imposed by the external donors and the difficulties to collect taxes from a population suffering high rates of unemployment caused a chronicle underfunding (Chanturidze et al., 2009). Moreover, the government was reluctant to downsize the larger-than-needed administrative and medical staff inherited from the soviet period (Shaapveld e Rhodes, 2004). 
The personnel thus absorbed the bulk of the limited resources the government could devote to the health sector (Gilauri, 2017).

As a consequence, Georgians had to purchase many of the services that were intended to be free. Out-of-pocket payments rose up to about 80 percent of total health expenditure (Belli et al., 2004). About 30 percent of Georgians were deterred from seeking medical services, while for about 50 percent of them access was very limited (Gamkrelidze et al., 2002; Collins, 2003).

\section{Health policy under Saakashvili}

Democratization in Georgia received new impetus from the Rose Revolution. At the end of 2003, despite some signals of economic recovery and a relatively good record in re-establishing central-state control in the separatist regions of South Ossetia and Abkhazia (Way, 2016, p. 156), Shevardnadze was forced to resign in the wake of a series of peaceful demonstrations against an irregular parliamentary election. A presidential election was held in January 2004, which the leader of the 2003 protests, former Ministry of Justice and pro-Western reformist Mikheil Saakashvili handily won with an impressive 96.9 percent.

While the result was clearly inflated by the Rose Revolution euphoria, the outcome of the vote largely reflected popular will for political change (OSCE. 2004). However, the new president soon revealed authoritarian tendencies (Way. 2016) and adopted a series of constitutional amendments to expand and centralize power in his own hands (Lanskoy and Areshidze. 2008; Dobbins. 2014). Saakashvili became the 'unchallenged master of parliament and the courts' (Fairbanks and Gugushvili. 2013, p. 117), engaged 'in endless manoeuvring designed to isolate, marginalize, and penetrate any sort of political opposition' (p. 118), manipulated the electoral code to favour his United National Movement (UNM), and attacked the independent media (Freedom House). 
These actions were aimed to remove the obstacles to the accomplishment of an ambitious plan of "modernization from above" (Gilauri, 2017). Saakashvili's developmental agenda included a large-scale privatization program aimed to fight state-level corruption, attract foreign investment and boost the economy (Timm, 2016). As part of this broader initiative, Saakashvili embarked in a radical restructuring of the national health system. Between 2004 and 2006, Shevardnadze's social insurance scheme was dismantled in favour of a system centred on private insurance and several public health institutions were abolished (Chanturidze et al., 2009, p. 84; Chikovani and Sulaberidze, 2017, pp. 11-14).

The shift to private insurance had inevitably tough consequences for many citizens, especially considering the still high unemployment rates and an economy that, in the mid2000s, had not yet fully recovered from the post-transition recession (Papava, 2013). Discontent was rising also with Saakashvili's dirigisme and a new wave of street demonstrations unfolded in the late summer of 2007 - the largest protest since the Rose Revolution (Lanskoy and Areshidze, 2008). Saakashvili initially responded with repression (International Federation for Human Rights, 2009). However, the protests did not stop, leading Saakashvili first to declare the state of emergency and then to concede early elections (RFE/RL, 2007).

In January 2008, Saakashvili was confirmed in office in a vote that fell short of a fully free and fair contest, characterized by the abuse of administrative resources (OSCE, 2008), with opposition parties coming from years of systematic marginalization and failing to run in a united front. Nevertheless, the 53.97 percent vote share that Saakashvili received marked a significant loss of the consensus he enjoyed in 2004 and represented quite a clear indicator of citizens' dissatisfaction (Nicol, 2008).

The relatively poor performance at the polls triggered a rapid re-orientation of Saakashvili's policy agenda, aimed to reconsolidate support among the poorer strata of the Georgian society. These citizens represented the main component of his supporters during the Rose Revolution 
(Fairbanks, 2004, p. 117), but also the social group that suffered the most from the neoliberal agenda implemented during Saakashvili's first term. In particular, 79 percent of Georgians living below the national poverty line identified affordable healthcare as one of the most critical issues (Caucasus Barometer, 2008).

Saakashvili thus abandoned the plan of 'turn[ing] health care into a regular economic sector' (Mendkovich, 2013, p. 79). In the inaugural speech of his second term, Saakashvili acknowledged that 'too many people [were] denied (...) health care' and indicated the delivery of 'social benefits to those who most need our help' as a priority (Saakashvili, 2008). Accordingly, a new Medical Assistance for the Poor (MAP, also known as Medical Insurance Program), previously piloted in Tbilisi and the Imereti region in 2007, was rolled out nationwide ahead of schedule in 2008, a few weeks before the legislative elections of May (Chikovani and Sulaberidze, 2017, p. 14; Chanturidze et al., 2009, p. 92).

Funded through general taxation, MAP funnelled public investment on the poorest segment of the Georgian society in the form of a package of free health services, according to a rather unique form of public-private partnership (Zoidze et al., 2012, p. 12). Private companies were responsible for reimbursing the healthcare providers, based on a contract with the Ministry of Labour Health and Social Affairs. Eligible beneficiaries were identified via a proxy means test. They received a voucher from the government with which they could buy health insurance. The government paid the premium directly to the private companies, which were in turn responsible for reimbursing the healthcare providers (Gotsadze et al., 2015, pp. 3-4).

By the end of 2008 , the poorest 18 percent of the Georgian population had private health insurance payed by the state (Chanturidze et al., 2009, p. 93). In the following years, moreover, MAP underwent a series of amendments aimed to expand both the beneficiaries and the package of services (Chikovani and Sulaberidze, 2017, p. 14). For instance, in 2009 MAP was extended to other social groups, such as teachers' households and orphans, which raised the coverage to 
20 percent of the population (Zoidze et al., 2012, p. 56). Another 2-3 percent of the Georgians who were not eligible for MAP was granted a subsidized "5-Lari" scheme (also known as "cheap insurance") covering unlimited visits for primary healthcare and a package of other basic services (Chanturidze et al., 2009, p. 38). In 2010, in turn, MAP was integrated by an Essential Medicines List subsidizing a limited amount of outpatient drug expenditures (Richardson and Berdzuli, 2017, p. 29).

\section{Health policy under Georgian Dream}

The end of Saakashvili's second and final term approaching, a series of events gave new impetus to political competition in Georgia. Despite several achievements in tackling poverty and a positive economic growth record, the president's strategy of "modernization from above" did not eradicate unemployment, did not benefit the Georgian population evenly (Perchoc, 2017 , p. 5), and often resulted in violations of civil liberties (Antelava and de Waal, 2013). ${ }^{5}$ As a consequence, new waves of protests occurred between 2009 and 2012 (Freedom House).

The mounting discontent favoured the formation in 2011 of a new opposition Georgian Dream (GD) party-then-coalition led by the tycoon Bidzina Ivanishvili with the goal of challenging Saakashvili’s UNM in the October 2012 parliamentary elections. These upcoming elections were a particularly important window of opportunity for opposition parties, as the new

\footnotetext{
${ }^{5}$ Georgia's defeat in the war with Russia (August 2008) is another issue on which Saakashvili was heavily criticized.
} 
parliament would have formed the government, following a 2010 constitutional amendment that shifted power from the president to the prime minister. ${ }^{6}$

The more competitive political environment gave social issues new centrality in the electoral campaign. GD was highly critical of the privatization of social services. In particular, while Saakahvili's MAP health scheme significantly increased access equity and service utilization by the poor (Gotsadze et al., 2015), affordable healthcare remained among the main priorities to be addressed, according to Georgians (Navarro and Woodward, 2012). The grievances of those citizens that were 'neither poor enough to receive free medical care, nor rich enough to afford (...) the premium of private health insurance' (Hauschild and Berkhout, 2009, p. 34) became one of the main grounds on which GD challenged the ruling party in the 2012 electoral campaign (Cohen and Benovic, 2016).

Ivanishvili accused the government to leave more than 70 percent of Georgians without medical care and indicated a free healthcare state program as the only viable strategy to achieve universal health coverage (Georgian Dream, 2012, pp. 31-35; Chikovani and Sulaberidze, 2017, p. 15). As a response, in September 2012 - that is, less than a month before the parliamentary election - Saakashvili extended MAP eligibility, which raised to 36 percent the share of the population that was insured by the state (Chikovani and Sulaberidze, 2017, p. 11). Furthermore, basic primary services were offered through a state primary healthcare program to other socially vulnerable groups, such as pensioners, people with disabilities, incurable patients, students and under-6 children (Richardson and Berdzuli, 2017, p. 30). A further expansion was promised aimed to grant insurance coverage for one out of two Georgians (Zoidze et al., 2012, p. 15).

\footnotetext{
${ }^{6}$ Initially, the reform was suspected to be a stratagem for Saakashvili to elude presidential term limits and seek re-election as Prime Minister, but his UNM party eventually run with another candidate (Fairbanks and Gugushvili, 2013).
} 
After an electoral campaign marked by Saakashvili's attempts to neutralize the opposition (Way, 2016), something "nearly unheard of" in post-soviet competitive authoritarian regimes happened in Georgia (Fairbanks and Gugushvili, 2013, p. 116). GD received 54.9\% of the ballots, Saakashvili graciously conceded defeat, and Ivanishvili was appointed as prime minister. ${ }^{7}$ To be sure, even this second episode of electoral turnover has failed to make Georgia fully democratic. Some flaws typical of competitive authoritarianism that have continued to characterize Georgia (or that have recently re-emerged) include electoral malpractices and biased media (Freedom House). Nonetheless, government alternation had profound health policy implications.

The new chief executive was swift in following up on his electoral vows (Cohen and Benovic, 2016). At the end of February 2013, Ivanishvili launched a Universal Health Coverage Program (UHCP, also known as "Health for all") aimed to extend free access to healthcare to almost the whole population. Administered by a new Social Service Agency, UHCP guarantees a basic package of primary health care and emergency medical care, which has been progressively expanded to encompass a range of health services similar to MAP (Richardson and Berdzuli, 2017). Initially, UHCP was targeted on uninsured citizens. Citizens previously enrolled to MAP were transferred to UHCP by April 2014 (World Bank, 2014). By the end of 2014, UHCP covered about 90 percent of Georgians (WHO, 2021). The extension of the entitlements to free health has been accompanied by a significant increase in government health spending (Richardson and Berzuli, 2017, p. 22).

Further efforts to address one of the endemic shortcomings of the health sector of postcommunist Georgia - namely, out-of-pocket payments - were made after the October 2016

\footnotetext{
${ }^{7}$ For clarity, the political process that led Georgia to experience the second episode of electoral government alternation in its history formally completed in October 2013, when Saakashvili arrived at the end of his second and final term and GD's candidate Giorgi Margvelashvili won the presidential election.
} 
parliamentary elections. Georgian Dream consolidated its dominance by winning about $76 \%$ of seats in a poll in which satisfaction with healthcare weighted significantly in determining voting decisions (Iakobidze, 2016). ${ }^{8}$ In particular, between 2017 and 2019 new measures were introduced aimed to expand the categories of citizens (including the poorest households, pensioners, and people with disabilities) eligible for free of charge outpatient medicines to treat common chronic diseases (WHO, 2021).

\section{Discussion}

The analysis highlights that, while post-Rose Revolution Georgia has experienced only partial democratic progress and a transition to competitive authoritarianism rather than to full-fledged democracy, the 2003 successful uprising against an undesired government has nonetheless inaugurated a new political phase for the country. Georgians have grown increasingly willing and able to voice their dissatisfaction, and the governments have faced progressively more compelling incentives to improve social services to elicit popular support.

Health policy has gained increasing centrality in the national political debate, especially near elections, and has been object of two major reforms aimed to reconcile financial sustainability and citizen accessibility. First, through the adoption of compensatory measures for the less welloff by an incumbent government that suffered in 2008 a significant loss of ballots. Subsequently, through the introduction of free healthcare, following a second episode of government turnover in 2012 and an electoral campaign highly focused on social issues.

\section{Conclusion}

\footnotetext{
${ }^{8}$ Giorgi Kvirikashvili, in office since 2015 (when he replaced Irakli Garibashvili, who in turn replaced Ivanishvili in 2013), was confirmed as prime minister.
} 
With a focus on health policy reforms in post-communist Georgia, this article examined whether and how partial democratization could draw rulers' attention to social needs in competitive authoritarian regimes. While scholars have already examined how transitions to democracy have shaped post-communist governments' approach to address the twofold challenge of taking care of an impoverished population and of restructuring the welfare state on financially sustainable models (Cook, 2007; Haggard and Kaufman, 2008; Orenstein, 2008), we know comparatively little regarding the effect of partial democratization, if any. We highlighted the importance that even rulers of competitive authoritarian regimes should attach to social services as a strategy to elicit 'specific support' (Easton, 1975) and the analysis of the Georgian case found empirical evidence of similar dynamics.

This research contributes to the debate on the welfare consequences of democratization (among others, Lake and Baum, 2001; Halperin et al., 2005) by shedding new light on the implications of partial democratic progress in post-communist competitive authoritarian regimes. Often, competitive authoritarianism is considered just a new dress for old settings (Carothers, 2002), that is, the result of a process of authoritarian transformation and adaptation. With no apologetic purpose for the non-democratic rulers of these regimes that have proliferated during the past three decades (in the post-communist area as well as in other world regions), this article offers a different perspective. The case of Georgia shows that even when political change stops short of full democratization and only leads to competitive authoritarianism, it could have positive social returns to the extent that it draws rulers' attention to the living conditions of the less well-off (Miller, 2015; Cassani, 2017; cf. Wang et al., 2019; Kim and Kroeger, 2018).

However, we should also acknowledge the limitations of the findings of this research, especially regarding the generalizability of our conclusions, which are drawn from the analysis of a single case, namely, the competitive authoritarian regime of a post-communist country. 
First, as an intermediate hybrid category that lies in between democracy and autocracy (Diamond, 2002; Levitsky and Way, 2010), competitive authoritarianism encompasses regimes that "mix" elements of competitive politics and authoritarianism in various ways. Moreover, we should consider that the Soviet legacy could influence the attention health policy receives in a post-communist country (Pop-Eleches and Tucker, 2017). With these caveats in mind, our findings are nonetheless consistent with and corroborate the conclusions of a few large- $\mathrm{N}$ analyses (Miller, 2015; Cassani, 2017) as well as of other small-N studies on hybrid regimes from other regions, such as sub-Saharan Africa (Stasavage, 2005; Kjær and Therkildsen, 2013; Travaglianti, 2017).

\section{References}

Antelava, N., and T. de Waal. 2013. "Debating Saakashvili: An Exchange on the Georgian President's Legacy.” Available online at: www.foreignaffairs.com/articles/russia-fsu/201312-09/debating-saakashvili accessed 25 February 2021.

Balcerowicz, L. 1994. “Understanding Post-Communist Transitions.” Journal of Democracy 5(4): 75-89.

Belli, P., G. Gotsadze, and H. Shahriari. 2004. "Out-of-Pocket and Informal Payments in Health Sector: Evidence from Georgia.” Health Policy 70(1): 109-123.

Bohle, D. and B. Greskovits. 2012. Capitalist Diversity on Europe's Periphery. Ithaca: Cornell University Press. 
Brusis, M. 2016. "The Politics of Legitimation in Post-Soviet Eurasia," In Politics and legitimacy in Post-Soviet Eurasia, edited by M. Brusis, J. Ahrens, and M. Schulze Wessel, 1-17. Basingstoke: Palgrave Macmillan.

Bueno de Mesquita, B., J. Morrow, R. Siverson, and A. Smith. 2003. The Logic of Political Survival. Cambridge: MIT Press.

Bunce, V. 2003. "Rethinking recent democratization: Lessons from the postcommunist experience.” World politics 55(2): 167-192.

Bunce V., and S. Wolchik. 2010. "Mixed Regimes in Post-communist Eurasia: Tipping Democratic and Tipping Authoritarian." In Democratization and Hybrid Regimes: International Anchoring and Domestic Dynamics in European Post-Soviet States, edited by E. Baracani, 57-86. Florence: European Press Academic Publishing.

Bunce, V., and S. Wolchik. 2010. "Defeating Dictators: Electoral Change and Stability in Competitive Authoritarian Regimes.” World Politics 62(1): 46-83.

Carbone, G. 2011. "Democratic Demands and Social Policies: The Politics of Health Reform in Ghana.” Journal of Modern African Studies 49(3): 381-408.

Carothers, T. “The End of the Transition Paradigm.” Journal of Democracy 13(1): 5-21.

Cassani, A., Luppi, F., and Gabriele Natalizia. 2016. "Pathways of Democratisation to Human Development in Post-communist Countries.” European Journal of Political Research 55(3): $512-30$.

Cassani, A. 2017. "Social Services to Claim Legitimacy: Comparing Autocracies' Performance." Contemporary Politics 23(3): 348-68.

CRRC. 2008. Caucasus Barometer, 2008. Available online at https://caucasusbarometer.org./en/cb2008ge/codebook/accessed 25 February 2021.

Chanturidze, T., T. Ugulava, A. Durán, T. Ensor, and E. Richardson. 2009. “Georgia: Health System Review." Health Systems in Transition 11(8): 1-116. 
Chikovani I., and L. Sulaberidze. 2017. "Primary Health Care Systems: Case study from Georgia." World Health Organization: 1-37.

Cohen A., and I. Benovic. 2016. “Georgian Dream Meets Reality: The Coalition's First Term and Future Reform Prospects." Institute for the Analysis on Global Security: 1-29.

Collins, T. 2003. "The Aftermath of Health Sector Reform in the Republic of Georgia: Effects on People's Health.” Journal of Community Health 28: 99-113.

Cook, L. 2007. Post-Communist Welfare States: Reform Politics in Russia and Eastern Europe. Ithaca: Cornell University Press.

Dahl, R. 1971. Polyarchy: Participation and Opposition. New Haven: Yale University Press.

Deacon, B. 2000. "Eastern European Welfare States: The Impact of the Politics of Globalization.” Journal of European Social Policy 10(2): 146-61.

Diamond, L. (2002). “Thinking About Hybrid Regimes.” Journal of Democracy 13(2): 21-35.

Dobbins, M. 2014. "The Post-Rose Revolution Reforms as a Case of Misguided Policy Transfer and Accidental Democratisation?" Europe-Asia Studies 66(5): 759-74.

Donno, D. 2013. Defending Democratic Norms: International Actors and the Politics of Electoral Misconduct. New York: Oxford University Press.

Easton, D. 1975. "A Re-Assessment of the Concept of Political Support." British Journal of Political Science 5(4): 435-57.

Fairbanks, C. and A. Gugushvili. 2013. "A New Chance for Georgian Democracy.” Journal of Democracy 24(1): 116-27.

Fairbanks, C. 2004. “Georgia's Rose Revolution.” Journal of Democracy 15(2): 110-24.

Fidrmuc, J. 2003. "Economic Reform, Democracy and Growth during Post-Communist Transition.” European Journal of Political Economy 19(3): 583-604.

Freedom House, (various years). Nations in Transit. Available online at https://freedomhouse.org/country/georgia/nations-transit/2020 accessed 25 February 2021. 
Gamkrelidze, A., R. Atun, G. Gotsadze, and L. MacLehose. 2002. "Health Care Systems in Transition: Georgia.” European Observatory on Health Care Systems 4(2): 1-72.

Georgian Dream. 2012. Political Coalition 'Georgian Dream’ Founding Act. Available online at www.ivote.ge/images/doc/pdfs/ocnebis\%20saarchevno\%20programa.pdf accessed 25 February 2021.

Gerschewski, J. "The Three Pillars of Stability: Legitimation, Repression, and Co-optation in Autocratic Regimes.” Democratization 20(1): 13-38.

Ghobarah, H., P. Huth, and B. Russett. 2004. "Comparative Public Health: The Political Economy of Human Misery and Well-being." International Studies Quarterly 48(1): 73-94.

Gilauri, N. 2017. Practical Economics: Economic Transformation and Government Reform in Georgia 2004-2012. London: Palgrave-Macmillan.

Gotsadze, G., A. Zoidze, N. Rukhadze, N. Shengelia, and N. Chkhaidze. 2015. "An Impact Evaluation of Medical Insurance for Poor in Georgia: Preliminary Results and Policy Implications." Health Policy and Planning 30(1): 2-13.

Grubel, H. "Economic Freedom and Human Welfare: Some Empirical Findings.” Cato Journal 18(2): 287-304.

Grünewald, A. 2021. "From Benefits and Beneficiaries: The Historical Origins of Old-Age Pensions From a Political Regime Perspective," Comparative Political Studies (February).

Haggard, S. and R. Kaufman. 2008. Development, Democracy, and Welfare States. Latin America, East Asia, and Eastern Europe. Princeton: Princeton University Press.

Hale, H. 2006. "Democracy or Autocracy on the March? The Colored Revolutions as Normal Dynamics of Patronal Presidentialism." Communist and Post-Communist Studies 39(3): 305-29.

Halperin, M., J. Siegle and M. Weinstein. 2005. The Democracy Advantage: How Democracies Promote Prosperity and Peace. New York: Routledge. 
Hauschild T., and E. Berkhout. 2009. "Health-Care Reform in Georgia: A Civil-Society Perspective: Country Case Study.” Oxfam International Research Report (May): 1-47.

Huber, E. and J. Stevens. 2012. Democracy and the Left. Social Policy and Inequality in Latin America. Chicago: The University of Chicago Press.

Iakobidze, T. 2016. "Undecided Voters in 2016: Leaning Towards a Multi-Party System?" Caucasus Analytical Digest 89: 2-5.

Inglot, T. Welfare States in East Central Europe, 1919-2004. Cambridge: Cambridge University Press.

International Federation for Human Rights. 2009. After the Rose, the Thorns: Political Prisoners in Post-Revolutionary Georgia. Available online at https://www.fidh.org/IMG/pdf/PolPrisGeorgia.pdf accessed 25 February 2021.

Kim, N.K., and A. Kroeger. 2018. "Do Multiparty Elections Improve Human Development in Autocracies?" Democratization 25(2): 251-72.

Kirchick, J. 2012. Georgian Dream Shows Its Dark Side. Available online at https://foreignpolicy.com/2012/11/29/georgian-dream-shows-its-dark-side/ accessed 25 February 2021.

Kjær, A. and O. Therkildsen. 2013. "Elections and Landmark Policies in Tanzania and Uganda." Democratization, 20(4): 592-614.

Knott, E. 2018. 'Perpetually 'Partly Free': Lessons from Post-soviet Hybrid Regimes on Backsliding in Central and Eastern Europe.” East European Politics 34(3): 355-76.

Knutsen, C.E., and M. Rasmussen. 2018. "The Autocratic Welfare State: Old-Age Pensions, Credible Commitments, and Regime Survival.” Comparative Political Studies 51(5): 65995.

Lake, D., and M. Baum. 2001. "The Invisible Hand of Democracy: Political Control and the Provision of Public Services.” Comparative Political Studies 34(6): 587-621. 
Lanskoy, M., and G. Areshidze. 2008. “Georgia's Year of Turmoil.” Journal of Democracy 19(4): $154-68$

Levitsky, S., and L. Way. 2010. Competitive Authoritarianism: Hybrid Regimes after the Cold War. Cambridge: Cambridge University Press.

Luciani, G. 1987. “Allocation vs. Production States: A Theoretical Framework.” In The rentier state edited by H. Beblawi, and G. Luciani, 63-82. London: Croom Helm and Istituto Affari Internazionali.

Mares, I., and M. Carnes. 2009. "Social Policy in Developing Countries." Annual Review of Political Science 12(1): 93-113.

McFaul, M. 2002. "The Fourth Wave of Democracy and Dictatorship: Noncooperative Transitions in the Postcommunist." World Politics 54(2): 212-44.

Meltzer, A., and S. Richard. 1981. "A Rational Theory of the Size of Government." Journal of Political Economy 89(5): 914-27.

Mendkovich, N. 2013. The Price of Reform: Or Why Georgia Has not Succeeded. Moscow: Russian Institute of Strategic Studies.

Miller, M. "Elections, Information, and Policy Responsiveness in Autocratic Regimes." Comparative Political Studies 48(6): 691-727.

Navarro, L., and I. Woodward. 2012. "Public attitudes in Georgia." National Democratic Institute (July).

Nichol, J. 2008. Georgia's January 2008 Presidential Election: Outcome and Implications. Washington: Congressional Research Service.

Nodia, G., and Á.P. Scholtbach. 2006. The Political Landscape of Georgia: Political Parties: Achievements, Challenges and Prospects. Delft: Eburon.

Olson, M. 1993. "Dictatorship, Democracy and Development." American Political Science Review 87(3): 567-76 
Orenstein, M. "Poverty, Inequality, and Democracy: Post-Communist Welfare States." Journal of Democracy 19(4): 80-94.

OSCE. 2004. Extraordinary Presidential Election, 4 January 2004. Available online at www.osce.org/odihr/elections/georgia/57862 accessed 25 February 2021.

OSCE. 2008. Extraordinary Presidential Election, 5 January 2008. Available online at https://www.osce.org/odihr/elections/georgia/57953 accessed 25 February 2021.

Papava, V. 2013. "Reforming of the Post-Soviet Georgia's Economy in 1991-2011.” Georgian Foundation for Strategic and International Studies - Centre for Applied Economic Studies.

Perchoc, P. 2017. "Georgia: European Engagement in an Unstable Environment.” European Parliamentary Research Service PE 599.287.

Pop-Eleches, G., and J. Tucker. 2017. Communism's Shadow: Historical Legacies and Contemporary Political Attitudes. Princeton: Princeton University Press.

Przeworski, A. 1991. Democracy and the Market: Political and Economic Reforms in Eastern Europe and Latin America. Cambridge: Cambridge University Press.

Radnitz, S. 2010. “The Color of Money: Privatization, Economic Dispersion, and the PostSoviet Revolutions." Comparative Politics 42(2): 127-46.

RFE/RL. 2007. Georgia: After Crackdown on Protests, President Calls Early Polls. Available online at www.rferl.org/a/1079100.html accessed 25 February 2021.

Richardson, E., and N. Berdzuli. 2017. "Health Systems in Transition: Georgia: Health System Review 2017." European Observatory on Health System and Policies.

Ross, M. 2006. "Is Democracy Good for the Poor?” American Journal of Political Science 50(4): 860-74.

Rudra, N., and S. Haggard. 2005. "Globalization, Democracy, and Effective Welfare Spending in the Developing World.” Comparative Political Studies 38(9): 1015-49. 
Timm, C. 2016. 2016. "Legitimacy and State-Led Economic Policy in Georgia," in Politics and legitimacy in Post-Soviet Eurasia edited by M. Brusis, J. Ahrens, and M. Schulze Wessel, 97-120. Basingstoke: Palgrave Macmillan.

Saakashvili, M. 2008. Inaugural Speech. Available online at www.saakashviliarchive.info/en/President/ accessed 25 February 2021.

Schaapveld, K., and G. Rhodes. 2004. "Observations on Health Financing Reform in the Republic of Georgia, 1996-2002.” Applied Health Economics and Health Policy 3(3): 12732.

Schedler, A. 2006. Electoral Authoritarianism: The Dynamics of Unfree Competition. Boulder: Lynne Rienner.

Sehngelia, L., M. Pavlova, and W. Groot. 2016. "Impact of Healthcare Reform on Universal Coverage in Georgia: A Systematic Review." Diversity and Equality in Health and Care 13(5): $349-56$.

Stasavage, D. 2005. "The Role of Democracy in Uganda's Move to Universal Primary Education.” The Journal of Modern African Studies 43(1): 53-73.

Stroup, M. 2007. "Economic Freedom, Democracy, and the Quality of Life." World Development 35(1): 52-66.

Svolik, M. 2012. The Politics of Authoritarian Rule. New York: Cambridge University Press. Travaglianti, M. 2017. "How Abolishing School Fees Increased Support for the Incumbent in Burundi.” African Affairs 116(462): 101-24.

Treisman, D. 2014. "The Political Economy of Change after Communism." In The Great Rebirth: Lessons From the Victory of Capitalism Over Communism edited by A. Aslund, and S. Djankov, 273-96: Washington: Peterson Institute for International Economics.

von Soest, C., and J. Grauvogel. 2017. "Identity, Procedures and Performance: How Authoritarian Regimes Legitimize Their Rule.” Contemporary Politics 23(3): 287-305. 
Wang, Y.-T., V. Mechkova, and F. Andersson. 2019. “Does Democracy Enhance Health? New Empirical Evidence 1900-2012.” Political Research Quarterly 72(3): 554-69.

Way, L. 2016. Pluralism by Default: Weak Autocrats and the Rise of Competitive Politics. Baltimore: JHU Press.

Way, L. 2010. "The New Authoritarianism in the Former Soviet Union.” Communist and postcommunist studies 43(4): 335-37.

WHO. 2021. Georgia: Profile of Health and Well-Being. World Health Organization.

Wintrobe, R. 2007. Dictatorship: Analytical Approaches. In The Oxford Handbook of Comparative Politics edited by C. Boix, and S. Stokes, 363-94. Oxford: Oxford University Press.

Wong, J. 2004. Healthy Democracies: Welfare Politics in Taiwan and South Korea. Ithaca: Cornell University Press.

World Bank. 1999. "Georgia Poverty and Income Distribution." Poverty Reduction and Economic Management Unit, Europe and Central Asia Region 19348-GE.

World Bank. 2002. Transition. The First Ten Years: Analysis and Lessons for Eastern Europe and the Former Soviet Union. Washington: World Bank.

World Bank. 2014. "Georgia Public Expenditure Review: Strategic Issues and Reform Agenda." Poverty Reduction and Economic Management Unit, Europe and Central Asia Region 78143-GE.

Zoidze, A., N. Rukhadze, K. Chkhatarashvili, and G. Gotsadze. 2012. Health Insurance for Poor: Georgia's Path to Universal Coverage? Curatio International Foundation. 
Table 1. Democracy and health expenditure in Georgia (1996-2019)

\begin{tabular}{|c|c|c|c|c|c|c|c|c|c|}
\hline Year & Leader/Party & $\begin{array}{c}\text { Electoral } \\
\text { democracy }\end{array}$ & $\begin{array}{c}\text { Freedom } \\
\text { Status } \\
\text { (score) }\end{array}$ & $\begin{array}{l}\text { DGGHE } \\
\text { (\% GDP) }\end{array}$ & $\begin{array}{l}\text { DGGHE } \\
\text { pc (US\$) }\end{array}$ & $\begin{array}{l}\text { DGGHE } \\
\text { (\% CHE) }\end{array}$ & $\begin{array}{c}\text { OOPE } \\
\text { (\% CHE) }\end{array}$ & $\begin{array}{c}\text { GDP pc } \\
\text { (US\$) }\end{array}$ & $\begin{array}{c}\text { GDP } \\
\text { growth } \\
(\%) \\
\end{array}$ \\
\hline 1996 & Shevardnadze/CUG & 0.38 & PF (4) & & & & & 689 & 11.20 \\
\hline 1997 & Shevardnadze/CUG & 0.38 & PF (3.5) & & & & & 807 & 10.52 \\
\hline 1998 & Shevardnadze/CUG & 0.38 & PF (3.5) & & & & & 852 & 3.10 \\
\hline 1999 & Shevardnadze/CUG & 0.38 & PF (3.5) & & & & & 674 & 2.87 \\
\hline \multicolumn{2}{|c|}{ term average 1996-1999 } & 0.38 & PF (3.62) & & & & & 755 & 6.92 \\
\hline 2000 & Shevardnadze/CUG & 0.38 & PF (4) & 0.84 & 5.92 & 11.41 & 80.98 & 750 & 1.84 \\
\hline 2001 & Shevardnadze/CUG & 0.39 & PF (4) & 1.17 & 8.75 & 15.84 & 76.44 & 802 & 4.81 \\
\hline 2002 & Shevardnadze/CUG & 0.39 & PF (4) & 1.15 & 9.20 & 14.36 & 77.13 & 854 & 5.47 \\
\hline 2003 & Shevardnadze/CUG & 0.39 & PF (4) & 1.18 & 11.10 & 14.29 & 79.21 & 1,010 & 11.06 \\
\hline \multicolumn{2}{|c|}{ term average 2000-2003 } & 0.39 & PF (4) & 1.09 & 8.74 & 13.97 & 78.44 & 854 & 5.79 \\
\hline 2004 & Saakashvili/UNM & 0.57 & PF (3.5) & 1.21 & 14.69 & 14.57 & 79.44 & 1,305 & 5.79 \\
\hline 2005 & Saakashvili/UNM & 0.57 & PF (3) & 1.24 & 18.87 & 14.92 & 79.59 & 1,643 & 9.59 \\
\hline 2006 & Saakashvili/UNM & 0.57 & PF (3) & 1.22 & 22.52 & 15.53 & 77.26 & 1,996 & 9.42 \\
\hline 2007 & Saakashvili/UNM & 0.56 & PF (4) & 1.12 & 27.44 & 14.70 & 75.67 & 2,635 & 12.58 \\
\hline \multicolumn{2}{|c|}{ term average 2004-2007 } & 0.57 & PF (3.37) & 1.2 & 20.88 & 14.93 & 77.99 & 1,895 & 9.35 \\
\hline 2008 & Saakashvili/UNM & 0.51 & PF (4) & 1.58 & 48.74 & 18.18 & 66.55 & 3,325 & 2.42 \\
\hline 2009 & Saakashvili/UNM & 0.50 & PF (4) & 2.11 & 55.07 & 21.42 & 68.91 & 2,823 & -3.65 \\
\hline 2010 & Saakashvili/UNM & 0.51 & PF (3.5) & 2.03 & 57.76 & 21.31 & 72.73 & 3,233 & 6.25 \\
\hline 2011 & Saakashvili/UNM & 0.51 & PF (3.5) & 1.47 & 51.87 & 17.48 & 75.61 & 4,022 & 7.40 \\
\hline 2012 & Saakashvili/UNM & 0.52 & PF (3) & 1.63 & 63.48 & 19.44 & 73.44 & 4,422 & 6.37 \\
\hline \multicolumn{2}{|c|}{ term average 2008-2012 } & 0.51 & PF (3.6) & 1.76 & 55.38 & 19.57 & 71.45 & 3,565 & 3.76 \\
\hline 2013 & Ivanishvili/GD & 0.63 & PF (3) & 1.98 & 78.85 & 23.56 & 69.08 & 4,624 & 3.62 \\
\hline 2014 & Garibashvili/GD & 0.67 & $\mathrm{PF}(3)$ & 2.33 & 95.30 & 27.60 & 65.98 & 4,739 & 4.43 \\
\hline 2015 & Garibashvili/GD & 0.68 & PF (3) & 2.82 & 98.12 & 35.57 & 57.32 & 4,014 & 3.02 \\
\hline 2016 & Kvirikashvili/GD & 0.69 & PF (3) & 3.09 & 110.49 & 36.64 & 55.52 & 4,062 & 2.91 \\
\hline \multicolumn{2}{|c|}{ term average 2013-2016 } & 0.67 & PF (3) & 2.55 & 95.69 & 30.84 & 61.97 & 4,360 & 3.50 \\
\hline 2017 & Kvirikashvili/GD & 0.71 & PF (3) & 2.63 & 106.43 & 37.21 & 54.76 & 4,357 & 4.84 \\
\hline 2018 & Kvirikashvili/GD & 0.69 & PF (3) & 2.81 & 123.41 & 39.46 & 47.67 & 4,722 & 4.84 \\
\hline 2019 & Bakhtadze/GD & 0.64 & PF (3) & & & & & 4,697 & 4.98 \\
\hline
\end{tabular}

Notes: PF = partly free; DGGHE = Domestic General Government Health Expenditure; GDP = Gross Domestic Product; $p c=$ per capita; USD = United States Dollars; $\mathrm{CHE}=$ Current Health Expenditure; OOPE = Out of Pocket Expenditure. The Electoral Democracy index ranges from 0 to 1 . The Freedom Score ranges from 7 (lowest) to 1 (highest).

Sources: Table compiled by the authors, based on data from Varieties of Democracy (https://www.v-

dem.net/en/data/data/v-dem-dataset/); Freedom House (https://freedomhouse.org/report/freedom-world); World Health Organization (https://apps.who.int/nha/database/ViewData/Indicators/en); World Bank (https://datatopics.worldbank.org/world-development-indicators/). 